\title{
Symbolism in A Rose for Emily
}

\author{
Yang Zhao \\ Foreign Languages College, Beihua University, Jilin 132013, China.
}

Keywords: symbolism, Faulkner, Emily

\begin{abstract}
William Faulkner is one of the greatest writers that America has produced. Since he was awarded the 1950 Nobel Prize for literature, his reputation and influence have spread to every part of the world. His brilliantly intensive fiction drew admiration from a growing number of writers and critics in America and France. In his short story A Rose for Emily, symbolism is used very frequently. Symbolism has a very deep and penetrating insight to the short story of A Rose for Emily. There are many different symbolic subjects such as Emily herself, her old house and the old servant. By analyzing these symbolic subjects, we can get a better understanding of this short story.
\end{abstract}

\section{Introduction}

Faulkner applies symbolism throughout the story and makes this simple story pregnant with meaning. This short story contains a high rate of symbolism, which is thoroughly distributed and revealed throughout the entire story. Symbolism is very prominent throughout the story, and plays one of the biggest roles in the underlying meaning of the entire story.

\section{Miss Emily}

In the beginning of the story the reader is informed that Emily is dead and the whole town goes to her funeral. Most of the people at the funeral were part of that young generation, and they could never really accept Emily into their generation. To them she was the classic idea of an old-fashioned southern woman. Miss Emily then becomes a symbol of the old generation's values and the sins of the old fathers. Many readers see Emily just as a symbol of the Past, but to a point that is not completely correct. On the other point, as the story goes on, the reader finds out that she is not really part of the old generation either. She, in fact, is part of the post-war generation, which was a defeated group that yearned for their Old World that they once had. The reader also find out that the new generation is nothing but a bunch of posers, because of the way they adapted their life to fit the American way. The new generation sees Greirsons as a high and mighty Power. They also inherited a land sullied with cotton garbage that commemorate the old south's defeat.

In the end, the narrator, a townsperson himself, reveals Miss Emily's real purpose. She was a reminder that both generations were guilty of the same misplaced value. Not only did they let Miss Emily, the murderess, come into being, but also that they covered up her crime and enshrined her in a tableau into which they can inset themselves. There is an interbreeding of ideas between the two groups that allow them to have such bad ideas in maintaining the ideas of what they would like to be. Miss Emily is a fallen monument not only to her family but also to the ends of the two generations. The monument is topped with death and not by the ethical evolution of the town. The narrator realizes it was the town's fault for Miss Emily's actions, because they drove her into isolation madness by treating her bad.

Miss Emily represents the old south. Her southern heritage and point of view are represented through her actions. Her stubbornness and unrelenting attitude are very strong characteristics of the southern heritage, and we can see this point from the south's attitude towards the slaves. She refused to believe that the times was changing. She refused to admit new things and new ideas. She refused to change into the new society. She stayed in her decaying house and went out little. People hardly saw her at all. She was refusing all of the new things in her own way. Though she cannot stop the times, she stops her own time, just as motionless water. The southern heritage is also represented through Miss Emily's strict and repetitive ways. The story basically addresses the 
changes in the south after the civil war. Miss Emily is considered a "monument" of southern manners and an ideal of past values. The old south generations were deteriorating very rapidly by changing traditions. When Miss Emily died, the "monument” was fallen, and Emily's generation was dying, so was the old south.

\section{Rose}

As we all know, roses stand for love. But in A Rose for Emily, by offering A Rose for Emily, the author is paying his sympathy and respect to Emily. As William Faulkner put it, Emily is an unfortunate woman. When she was young and beautiful, she lived in a tower built by her dominating, stubborn father. It wasted her most beautiful age as a woman. After her father's death, with the collapse of the powerful tower, Emily did not know what to do and how to live on, so she refused to admit her father's death. We can see this point from the original edition: the day after his death all the ladies prepared to call at the house and offer condolence and aid, as is our custom. Miss Emily met them at the door, dressed as usual and with no trace of grief on her face. She told them that her father was not dead. She did that for three days, with the ministers calling on her, and the doctors, trying to persuade her to let them to dispose of the body. Just as they were about to resort to law and force, she broke down and they buried her father quickly. Then she met Homer Barron, a Yankee, an unmarried man and fell in love with him. So she was doomed to be jilted. In addition, the rose here also stands for blood and death. In A Rose for Emily, color of the rose is red. So is blood. Roses are beautiful but also full of thorns. It hurts Emily physically and mentally. We know that in Emily's wedding room everything is rosy. In fact both Emily and Homer Barron are killed by the rose, the very symbol of love. However Emily is killed by her deep, abnormal love while Homer Barron by irresponsible love.

Rose symbolizes love in western culture while presenting bouquet shows reverence. A Rose for Emily, to some degree, extends heart-felt respect on people of the town to Emily, the last if the long line of the southern "aristocrats". She is typified as the mark of the old fallen southern aristocrats after Civil War. So when she appears with Homer Barron intimately, all the ladies believe she was fallen and that was a disgrace to the town and a bad example to the young people. When Emily goes to buy arsenic they thought she would kill herself and nothing else is a better resolution. Some old people even appear in the funeral of Emily in their brushed Confederate uniforms. It is thus clear that how important Emily is in the eyes of the people of the town as the phantom of old aristocrat Faulkner made A Rose for Emily the title to express the reverence of the people in the town and their nostalgia of old south. Take "rose" as love, A Rose for Emily can be interpreted into " love for Emily ". In terms to this, Faulkner adopts metaphor to multiply unsuccessful love of Emily which eventually turns into tragedy. There is certain relationship between the decayed body and the rose. The author does not breathe a single word about rose, only used ingenious devices to keep the audience in suspense. As a matter of fact, the story is a homicide tragedy about love, not approved by the broad masses of readers. The sick love of Emily is also a kind of love.

\section{The house}

Miss Emily's house is an important symbol in this story. (In general, old family homes are often significant symbols in Gothic literature.) For most of the story, we, like the townspeople, only see Miss Emily's house from the outside looking in.

The fact that the house was built in the 1870s tells us that Miss Emily's father must have been doing pretty well for himself after the Civil War. The narrator's description of it as an "eyesore among eyesores" is a double or even triple judgment. The narrator doesn't seem to approve of the urban sprawl. We also speculate that the house is an emblem of money probably earned in large part through the labors of slaves, or emancipated slaves. The final part of this judgment has to do with the fact that the house was allowed to decay and disintegrate. For an idea of the kind of house Miss Emily lived in, take a look at artist Thorea Hamlet's house in Mississippi, built, like Emily's, in the 1870. Now picture the lawn overgrown, maybe a broken window or two, the paint worn and 
chipping and you have a creepy house that Emily lived in, and which the children of the "newer generation" probably ran past in a fright.

The house, as is often the case in scary stories, is also a symbol of the opposite of what it's supposed to be. Like most human beings, Emily wanted a house she could love someone in, and a house where she could be free. She thought she might have this with Homer Barron, but something went terribly wrong. This something turned her house into a virtual prison - she had nowhere else to go but home, and this home, with the corpse of Homer Barron rotting in a room upstairs, could never be shared with others. The house is a huge symbol of Miss Emily's isolation.

\section{Homer Barron}

Homer Barron, a Yankee, a big, dark, ready man, represents the north. He is a foreman of the project of paving the sidewalks. He brings machines to the south. He has newfangled views, such as to be an unmarried man. "Pretty soon he knew everybody in town, whenever you heard a lot of laughing anywhere about the square, Homer Barron would be in the center of the group." It shows that the persons in the Jefferson town like him, or even welcome him. These persons of the south listen to a Yankee and make him the center of their group. So we can say that the town can accept the new things from the north. What about Miss Emily? She fell in love with this Yankee and even wanted to marry him. But finally "the north" abandoned "the south". Miss Emily, a southern aristocratic woman; Homer Barron, a Yankee; the conflict between them can be seen as the conflict between the south and the north. The south is known for being traditional, and the north is known for being very adaptable to change. Homer Barron was from the north and also represented "the next generation" with its more modern ideas. He has a short relation with Miss Emily and he thinks it normal. But for Miss Emily, it seems to be unbelievable and unacceptable. In A Rose for Emily, Emily murdered Homer Barron and lived with his body for many years. In some sense, she conquered time. Can we say the south conquered the north whatever method it used? Homer Barron is a typical character who carries the kind of Bourgeois moral values. He sought for private interest and lacked in moral disciplines; he indulged in wine and women but refused to bear any moral responsibilities. He dated Miss Emily overtly, but was not a marrying man. He was not serious about love. He just flirted. With Miss Emily-a representative of the old moral values. Homer's moral values form a sharp contrast of hers. They couldn't be together. The only way of solving the conflict was using violence. It was inevitable and also the result of moral conflicting. But Faulkner wants to remind the readers, while the human-beings are discarding those old, out of date things and adopting the more ruthless and ambitious ways of the industrialization and mechanization, how can we retain the fine qualities, preserve the splendid culture, and establish friendly relations with Nature? This is what every human-being should think over. Through this ending, we can infer the author's attitude towards the south. He has a very complex feeling towards the south, his hometown. He is connected with the south and hates it meanwhile. He doesn't like what the north has brought, either. With Emily's death, we can say William Faulkner admits the south’s death finally.

\section{Conclusion}

Today William Faulkner is considered to be the greatest writer of fiction that the United States has produced. In his novels, each place, or even a modifier, bears not only its own unique implication but further induces a variety of subjective interpretations from its readers. In A Rose for Emily, Faulkner's famous short story, there are many symbolic subjects. By analyzing them we can have a deeper understanding of this story and William Faulkner's writing skills. Although A Rose for Emily is a short story, and not regarded as a typical work of Faulkner, it really reveals Faulkner's unique writing skills. Faulkner pursues an artistic writing style which is connected closely with the realistic world. He brings the questions to the reader not only through the simple fact but his complex form which always makes the reader immersed with his soar thought. He seldom puts emphasis on reality, but on symbolic approach to literature in order to discover the truth of human heart. He emphasizes the symbolic relationship among characters. His stories are based on reality, 
but the symbolic technique makes him different from the realists. His use of symbolism makes each of his works unfold a story of universal interest, especially his short story A Rose for Emily. In this sense, he has the ability to attract the reader's attention to his point.

\section{References}

[1]Philip M Weinstein. The Cambridge Companion to William Faulkner[J].Shanghai: ShangHai Foreign Language Education Press,2000.

[2]Rubinstein, Annette T. American Literature Root and Flower [M].Beijing Foreign Language Teaching and Research Press,1998.

[3]Wu Weiren. History and Anthology of American Literature [M].Beijing: Foreign Language Teaching and Research Press,1990.

[4]Yuan Xianjun. Approaching Fiction[M]. Beijing: Peking University Press, 2004. 